\title{
KETERSEDIAAN DAN POLA PEMBERIAN AIR PADA DAERAH IRIGASI ENDIKAT BENGKOK KABUPATEN MUARA ENIM
}

\author{
Reni Andayani 1), Ayu Marlina ${ }^{2)}$ \\ 1,2) Program Studi Teknik Sipil Fakultas Teknik Universitas Tridinanti Palembang, \\ Jl. Kapten Marzuki No.2446 Kamboja Palembang
}

\section{Abstract}

Endikat Bengkok irrigation area located in Muara Enim with area of 1,140 ha. The Endikat Bengkok Irrigation channel used to irrigate rice fields in four villages, namely Segamit, Siring Agung, Arimantai and Fajar Bulan, districts of Semendo Barat Ulu. The source of irrigation water are available in the Endikat Bengkok River, which is a subsidiary of the Lematang River. The purpose of this study was to analyze the water availibility in the Endikat Bengkok River for the adequacy of the Endikat Bengkok Irrigation Area, and the appropriate water provision group. Primary data was collected in the form of the planting group, secondary data in the form of rainfall data and climatological data. The calculation of evapotranspiration used the Penman method and the calculation of water availability used the F.J. Mock. From the calculation of water availability showed that the maximum value occurred in April amounted to $48.15 \mathrm{~m}^{3} / \mathrm{s}$ and the minimum value occurred in October amounted to $2.23 \mathrm{~m}^{3} / \mathrm{s}$. The availability of water for irrigation $(80 \%$ dependable flow) is not sufficient to irrigate the entire Endikat Bengkok Irrigation Area. The most suitable water supply group by rotating based on the provisions of the irrigation planning criteria.

Key Words: dependable flow, Mock method, water availability, water supply.

\section{PENDAHULUAN}

Sistem irigasi di Indonesia bertujuan membawa air irigasi ke daerah-daerah yang harus diairi serta membagi-baginya secara logis sehingga mencukupi hingga ke petak terbawah. Persawahan di Indonesia umumnya dijalankan secara menggenang, karena umumnya bertujuan menolong tanaman padi pada masa pertumbuhannya. Irigasi di Indonesia terbagi menjadi irigasi sederhana, irigasi semi semi teknis dan daerah irigasi teknis.

Sumatera Selatan memiliki beberapa Daerah Irigasi (DI), salah satunya adalah Daerah Irigasi Endikat Bengkok. Daerah irigasi Endikat Bengkok berada di Kabupaten Muara Enim Provinsi Sumatera Selatan. Irigasi Endikat Bengkok berfungsi, untuk mengaliri persawahan di empat desa yaitu desa Segamit, Siring Agung, Arimantai dan desa Fajar Bulan kecamatan Semendo Barat Ulu. Kecamatan Semendo Barat Ulu memiliki luas total $46.660 \mathrm{Ha}$.

Daerah irigasi Endikat Bengkok mendapatkan sumber air dari Sungai Endikat Bengkok, dengan hulu sungai berada di wilayah Lahat dan Pagar Alam, dan merupakan anak dari Sungai Lematang. Seperti kebanyakan daerah irigasi di Indonesia, DI Endikat Bengkok dijalankan dengan sistem pengaliran gravitasi.Daerah irigasi Endikat Bengkok hingga kini telah dicetak seluas 1140 hektar. Kenyataannya terjadi pada saat pre survey dengan petani adanya kekurangan air pada jaringan irigasi
Endikat Bengkok khususnya pada desa-desa dengan petak bagian bawah jaringan, yaitu pada desa Arimantai dan Fajar Bulan.

Dari permasalahan dilapangan, maka perlu dilakukan penelitian mengenai ketersediaan air Sungai Endikat Bengkok untuk irigasi (debit andalan Q80), serta analisis pola pemberian air agar mendapatkan solusi kecukupan air irigasi tersebut. Beberapa penelitian yang telah dilakukan yaitu, Analisis Ketersediaan dan Kebutuhan Air di Sungai Lahat Untuk Daerah Irigasi Lahat Sampai Tahap-I Fase-2 (Sari dkk., 2011), Analisis Kebutuhan Air Irigasi, Studi Kasus Pada Daerah Irigasi Sungai Air Keban Daerah Kabupaten Empat Lawang (Priyonugroho, 2014), Analisis Ketersediaan dan Kebutuhan Air pada Bendung Perjaya Sungai Komering 2 (Wijaksono dkk, 2018), Analisa Ketersediaan Air Sungai Talawan Untuk Kebutuhan Irigasi di Daerah Irigasi Talawan Meras dan Talawan Atas (Kundimang dkk., 2015)

\section{METODOLOGI}

Lokasi penelitian di daerah Irigasi Endikat Bengkok yang terletak di empat Desa yaitu desa Segamit, desa Siring Agung, desa Aremantai, dan desa Fajar Bulan Kecamatan Semende Darat Ulu Kabupaten Muara Enim. Letak Geografis Daerah Irigasi (DI) Irigasi Endikat Bengkok terletak antara $4^{\circ} 10^{\prime}-4^{\circ} 20^{\prime}$ Lintang Selatan dan $103^{\circ} 20^{\prime}-103^{\circ}$ $40^{\prime}$ Bujur Timur dan berada di Kabupaten Muara 
Reni Andayani \& Ayu Marlina | Ketersediaan dan Pola Pemberian Air pada Daerah Irigasi Endikat Bengkok Kabupaten Muara Enim Cantilever | Volume : 9 | Nomor : 2 | Oktober 2020 | Hal. 83-88 | ISSN: 1907-4247 (Print) | ISSN: 2477-4863 (Online) | Website: http://cantilever.id

Enim. Daerah Irigasi ini direncanakan dicetak seluas $1800 \mathrm{Ha}$, namun kondisi eksisting baru $1140 \mathrm{Ha}$. Sumber air irigasi Endikat Bengkok berasal dari Sungai Endikat Bengkok. Data primer yang diambil berupa data pola tanam. Data pola tanam didapat dari wawancara dengan Perhimpunan Petani Pengguna Air, yang gunanya untuk menghitung kebutuhan air. Data sekunder berupa data curah hujan bulanan selama periode 10 tahun dan data klimatologi Pos Hujan Pulau Panggung Kabupaten Muara Enim (Gambar 1).

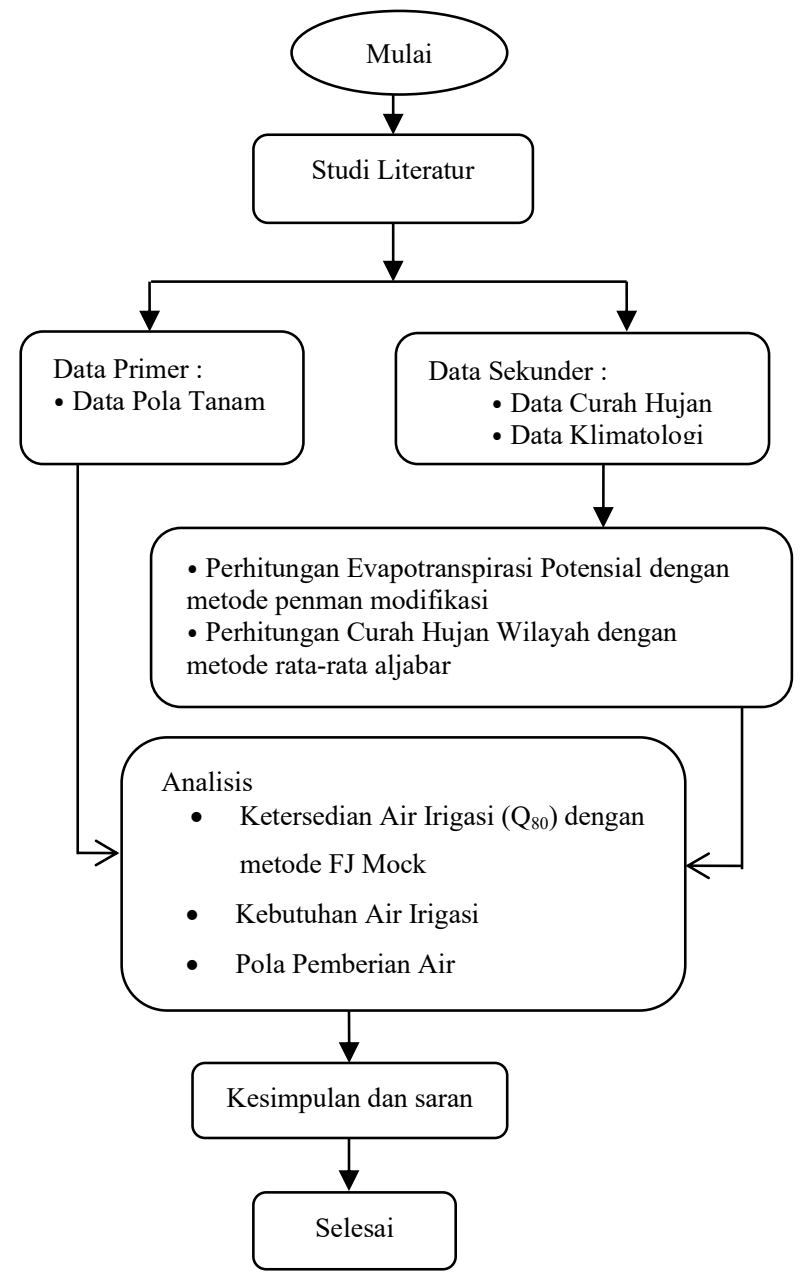

Gambar 1. Bagan Alir Penelitian

\section{HASIL DAN PEMBAHASAN}

\subsection{Analisis Ketersediaan Air Irigasi}

\section{Analisis Data Klimatologi}

Data klimatologi yang akan diolah meliputi data kecepatan angin, kelembaban udara, temperatur udara rata - rata dan lama penyinaran matahari yang berguna untuk menghitung penguapan atau evapotranspirasi potensial. Data Klimatalogi didapat dari BMKG Kelas 1 Kenten Palembang selama 1 tahun yaitu tahun 2016 (Tabel 1). Perhitungan evapotranspirasi menggunakan metode Penmann modifikasi (Tabel 2).

\section{Analisis Data Curah Hujan}

Untuk perhitungan curah hujan kawasan digunakan data curah hujan rata-rata selama 10 tahun dari pos hujan Pulau Panggung dan Muara Enim tahun 2007 - 2016 yang dianalisis dengan metode rata-rata aljabar (Tabel 3).

Tabel 1. Data Klimatologi Pulau Panggung Muara Enim

\begin{tabular}{|c|c|c|c|c|c|c|c|c|c|c|c|c|c|}
\hline Irian & \begin{tabular}{|l|l|} 
Satuan \\
\end{tabular} & \begin{tabular}{|l|} 
Jan \\
\end{tabular} & Feb & \begin{tabular}{|l|l|} 
Mar \\
\end{tabular} & Apr & Mei & Jin & Jul & Agt & Sep & Okt & & Des \\
\hline Teaportmitenth & ${ }^{\circ} \mathrm{C}$ & 27.5 & 272 & 27.82 & 28.1 & 28.2 & 27.8 & 27.9 & & 2 & 2 & & 275 \\
\hline 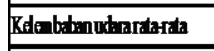 & $\mathbf{x}$ & 85.4 & 85.8 & 85.1 & 85.1 & 85.1 & 82.6 & 80,8 & 76.7 & 80.9 & 822 & 82.7 & 83.5 \\
\hline 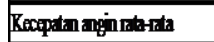 & n/tat & 3 & 3.1 & 2.7 & 2.5 & 2.4 & 2.8 & 3.3 & 3.7 & 32 & 3 & 1.7 & 2 \\
\hline Peryjananm: & \% & 24.8 & 23.6 & 27.9 & 23.7 & 20 & 13.6 & 18.7 & 206 & 206 & 18.8 & 17.8 & 152 \\
\hline
\end{tabular}

Tabel 2. Nilai Evapotranspirasi Potensial

\begin{tabular}{|l|c|c|c|c|c|c|c|c|c|c|c|c|}
\hline Bulan & Jan & Feb & Mar & Apri & Mei & Juni & Juli & Agus & Sept & Okt & Nov & Des \\
\hline
\end{tabular} \begin{tabular}{|l|l|l|l|l|l|l|l|l|l|l|l|}
\hline Eto (mm/bula 102 & 120 & 121 & 117 & 126 & 122 & 131 & 147 & 149 & 140 & 119 & 118 \\
\hline
\end{tabular}

Tabel 3. Curah Hujan Rata-Rata Bulanan Kawasan Pulau Panggung dan Muara Enim

\begin{tabular}{|c|c|c|c|c|c|c|c|c|c|c|c|c|}
\hline & in & b & M & & Mei & Juni & Juli & ggustuy & Sept & Okt & Nov & e \\
\hline 2007 & 433 & 346 & \begin{tabular}{|l|}
243 \\
\end{tabular} & 408 & 297 & 148 & 83 & \begin{tabular}{|c|}
103 \\
\end{tabular} & 88 & 201 & 191 & \\
\hline ri Hujan & 19 & $\mathbf{8}$ & 15 & 21 & 14 & & & & & 10 & 16 & \\
\hline 08 & 135 & 37 & 229 & 268 & 257 & 244 & 135 & 245 & 161 & 196 & 344 & \\
\hline i Hujal & & & & 14 & & & & 10 & 14 & 18 & & \\
\hline & 430 & 213 & 343 & 431 & 243 & 37 & 162 & 191 & 263 & 298 & 167 & \\
\hline & & & 4 & 17 & & & & 14 & & 77 & & \\
\hline 010 & 418 & 335 & 385 & 276 & 215 & 129 & 378 & 221 & 317 & 286 & 448 & \\
\hline i Hujan & & & & 13 & & & & & 5 & 21 & 20 & \\
\hline 20111 & 359 & 160 & 290 & 302 & 305 & 177 & 118 & 128 & 22 & 182 & 359 & \\
\hline riHujan & 19 & & 15 & 17 & & & 10 & & & 22 & 20 & \\
\hline 2012 & 316 & 373 & 219 & 278 & 251 & 163 & 125 & 22 & 66 & 170 & 433 & \\
\hline jan & 11 & & 17 & 20 & 13 & 13 & 12 & & 10 & 13 & & \\
\hline & 299 & 198 & 164 & 461 & 462 & 117 & 142 & 139 & 1981 & 138 & 208 & \\
\hline jan & 19 & & 10 & 17 & 14 & & 12 & 10 & & 25 & 23 & \\
\hline & 306 & 316 & \begin{tabular}{|l|}
316 \\
\end{tabular} & 352 & 265 & 94 & 36 & 37 & 55 & 76 & 207 & \\
\hline jan & 2 & 1 & & 15 & 12 & 10 & 14 & & & 12 & 15 & \\
\hline & 304 & 301 & 301 & 382 & 190 & 88.5 & 375 & 38.5 & 46 & 139 & 254 & 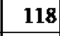 \\
\hline jan & 1 & 1 & 1 & 16 & & & & 6 & 2 & 6 & 25 & \\
\hline 2016 & 250 & 457 & 471 & 643 & 403 & 121 & 313 & 110 & 344 & 256 & 329 & 20 \\
\hline njan & 19 & 22 & 20 & 22 & 20 & 12 & 12 & 12 & 13 & 13 & 22 & \\
\hline
\end{tabular}

\section{Analisis Debit Andalan}

Debit andalan adalah debit yang di harapkan selalu tersedia sepanjang tahun dengan resiko kegagalan yang diperhitungkan sekecil mungkin. Dalam penelitian ini ditetapkan debit andalan untuk keperluan irigasi sebesar $80 \%$ sesuai dengan Kriteria Perencanaan Irigasi. Untuk menganalisis debit andalan terlebih dahulu dilakukan analisis debit limpasan menggunakan metode F.J. Mock. Besarnya parameter permukaan lahan terbuka $(m)$ F.J. Mock yaitu nilai Expose Surface (m) diasumsikan 35\% karena lahan dominan berupa lahan pertanian. Koefisien infiltrasi berdasarkan kondisi porositas tanah dan kemiringan daerah pengaliran. Untuk daerah ini ditaksir harga $i$ sebesar 0,5 . Faktor resesi aliran air tanah yang ditaksir sebesar 0,6 . 
Cantilever | Volume: 9 | Nomor: 2 | Oktober 2002 | ISSN: 1907-4247 (Print) | ISSN: 2477-4863 (Online) | Website: http://cantilever.id Reni Andayani \& Ayu Marlina | Ketersediaan dan Pola Pemberian Air pada Daerah Irigasi Endikat Bengkok Kabupaten Muara Enim

Langkah - langkah analisis debit aliran yang tersedia dengan model F.J. Mock adalah (contoh pada bulan April 2009):

1. Input data curah hujan bulanan

2. Menentukan nilai evapotranspirasi aktual $\left(E t_{a}\right)$

a. Input data Evapotranspirasi potensial $\left(E T_{p}\right)$ pada bulan April 2009 yang diperoleh dari perhitungan sebelumnya, sebesar 117,3 $\mathrm{mm} / \mathrm{bln}$.

$b$. Besarnya parameter permukaan lahan terbuka (m) F.J. Mock dari tabel 2.1, yaitu nilai Expose Surface (m) diasumsikan 35\% karena lahan dominan berupa lahan pertanian. $\mathrm{m} / 20(18-\mathrm{na})=0,35 / 20(18-17)=0,0175$

3. Menentukan keseimbangan air dalam tanah.

a. Menghitung air hujan yang mencapai permukaan tanah $(\Delta S)$

$$
\begin{aligned}
\Delta S & =P-E T_{O}(E a) \\
& =431-115,247 \\
& =315,753 \mathrm{~mm} / \mathrm{bln}
\end{aligned}
$$

4. Menentukan aliran dan tampungan air tanah

a. Menghitung besarnya Infiltrasi (I).

$$
\begin{aligned}
I \quad & W S . i \\
& =315,753 \times 0,5 \\
& =157,876 \mathrm{~mm} / \mathrm{bln}
\end{aligned}
$$

$i$ adalah koefisien infiltrasi berdasarkan kondisi porositas tanah dan kemiringan daerah pengaliran. Untuk daerah ini ditaksir harga $i$ sebesar 0,5 .

b. Menghitung nilai $\alpha$

$$
\begin{aligned}
0,5 \cdot(1+k) I & =0,5 \cdot(1+0,6) \cdot 157,876 \\
& =126,301 \mathrm{~mm} / \mathrm{bln}
\end{aligned}
$$

$k$ adalah faktor resesi aliran air tanah yang ditaksir sebesar 0,6.

c. Menghitung kandungan air tanah

$$
\text { k. } \begin{aligned}
V_{(n-1} & =0,6 \cdot 163,241 \\
& =97,945
\end{aligned}
$$

$V_{(n-1)}$ adalah kandungan air tanah pada bulan sebelumnya dikali dengan volume penyimpanan $(\mathrm{Vn})$.

d. Menentukan besarnya volume penyimpanan air tanah $\left(V_{n}\right)$

$$
\begin{aligned}
V_{n} & =k \cdot V_{n-1}+1 / 2(1+k) . I \\
& =97,945+126,301 \\
& =224,246 \mathrm{~mm} / \mathrm{bln}
\end{aligned}
$$

e. Menentukan perubahan volume air $\left(d V_{n}\right)$

$$
\begin{aligned}
d V n & =V_{n}-V_{n-1} \\
& =224,246-163,241 \\
& =61,005 \mathrm{~mm} / \mathrm{bln}
\end{aligned}
$$

\begin{tabular}{|c|c|c|c|c|c|c|c|c|c|c|}
\hline \multirow{2}{*}{ Periode } & \multicolumn{10}{|c|}{ Tahun } \\
\hline & 2007 & 2008 & 2009 & 2010 & 2011 & 2012 & 2013 & 2014 & 2015 & 2016 \\
\hline h. & 59.74 & 6.42 & 59.20 & 57.05 & 4650 & 38.81 & 35.76 & 37.02 & 36.66 & 27.00 \\
\hline Fo & 63.27 & 25.94 & 36.76 & 60.30 & 2252 & 62.43 & 26.87 & 42.49 & 49.12 & 75.59 \\
\hline Mar & 43.53 & 27.29 & 55.37 & 65.33 & 40.95 & 36.61 & 2039 & 49.57 & 49.02 & 83.24 \\
\hline Apr & 72.82 & 37.73 & 78.49 & 54.09 & 48.72 & 46.16 & 72.48 & 61.71 & 67.64 & 127.22 \\
\hline Mei & 57.09 & 39.49 & 51.99 & 43.37 & 53.61 & 41.73 & 8325 & 67.13 & 39.06 & 92.05 \\
\hline J & 24.32 & 15.33 & 23.54 & 19.51 & 20.72 & 17.43 & 3038 & 26.02 & 18.85 & 40.01 \\
\hline Jal & 14.12 & 8.90 & 13.67 & 11.33 & 12.03 & 10.12 & 17.64 & 15.11 & 10.95 & 23.23 \\
\hline Agess & 8.47 & 5.34 & 8.20 & 6.80 & 7.22 & 6.07 & 1058 & 9.06 & 6.57 & 13.94 \\
\hline Sqt & 5.25 & 3.31 & 5.08 & 4.21 & 4.48 & 3.76 & 6.56 & 5.62 & 4.07 & 8.64 \\
\hline Old & 3.05 & 1.92 & 2.95 & 2.45 & 2.60 & 2.19 & 3.81 & 3.26 & 2.36 & 5.02 \\
\hline Now & 15.18 & 42.77 & 10.69 & 62.32 & 45.96 & 5939 & 18.80 & 18.27 & 26.41 & 41.92 \\
\hline Des & 28.08 & 13195 & 62.50 & 60.34 & 38.44 & 8852 & 56.00 & 25.70 & 7.29 & 27.14 \\
\hline
\end{tabular}

f. Menentukan besarnya aliran dasar $(B F)$

$$
\begin{aligned}
B F & =I-d V_{n} \\
& =157,876-61,005 \\
& =96,872 \mathrm{~mm} / \mathrm{bln}
\end{aligned}
$$

g. Menentukan besarnya aliran (TRO)

$\mathrm{TRO}=B F+D R_{0}$

$$
=96,872+157,876
$$$$
=254,748 \mathrm{~mm} / \mathrm{bln}
$$

5. Menentukan debit limpasan sungai pada DAS

\begin{tabular}{|c|c|c|c|c|c|c|c|c|c|c|c|}
\hline \multirow{2}{*}{\multicolumn{2}{|c|}{$P=\frac{m}{n+1} \mathrm{I} 100 \%$}} & 1 & 2 & 3 & 4 & 5 & 6 & 7 & 8 & 9 & 10 \\
\hline & & $9 \%$ & $18 \%$ & $27 \%$ & $36 \%$ & $5 \%$ & $55 \%$ & $64 \%$ & $73 \%$ & $2 \%$ & $91 \%$ \\
\hline \multirow{3}{*}{ 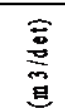 } & $\mathrm{Jn}$ & 59.74 & & 7.05 & 50 & 8.81 & 7.02 & 6.66 & 5.76 & & 6.42 \\
\hline & F由 & & & & & & & & & & 22.5 \\
\hline & Mar & & & & & & & & & & \\
\hline \multirow{3}{*}{ 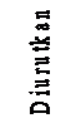 } & & & & & & 1.64 & & & 40.12 & & 37.7 \\
\hline & $\mathbf{M e}$ & & & $07 . \mathrm{S}$ & & 1.09 & & & 1.75 & 39.49 & 39.06 \\
\hline & Jan & 40.01 & & 26.02 & & 3.54 & 772 & & 8.85 & 7.43 & 15.3 \\
\hline \multirow{2}{*}{$\underset{\infty}{\infty}$} & Jal & 23.23 & 76 & 15.11 & & 3.67 & 12.03 & & 0.95 & 1012 & 8.90 \\
\hline & Agus & 13.94 & 10.50 & 006 & 0.47 & 8.20 & 722 & & 6.57 & 6.07 & 5.34 \\
\hline \multirow{4}{*}{ 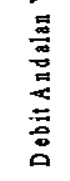 } & S甲t & 8.64 & 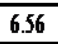 & 5.02 & $3 . D$ & 3.08 & 4.48 & & 4.07 & 3.76 & 3.31 \\
\hline & Olt & 5.02 & 3.81 & 3.26 & 3.03 & 2.95 & 2.60 & & 2.36 & 2.19 & 1.92 \\
\hline & $\mathrm{Ner}$ & 62.32 & 59.39 & 45.96 & 42.77 & 41.92 & 26.41 & & 18.27 & 15.18 & 10.69 \\
\hline & Des & 131.95 & 88.52 & 62.50 & 6034 & 56.00 & 38.44 & 28.08 & 27.14 & 25.70 & 729 \\
\hline
\end{tabular}

$$
Q=A \cdot x \operatorname{TR} O x\left(\frac{1}{n x 86,4}\right)=78,49 \mathrm{~m}^{3} / \mathrm{dt}
$$

Sehingga, besarnya debit limpasan pada sungai Endikat Bengkok pada bulan April 2009 adalah sebesar 78,49 $\mathrm{m}^{3} / \mathrm{dt}$. Rekapitulasi hasil perhitungan debit limpasan dengan metode FJ Mock dapat dilihat pada Tabel 4 .

Tabel 4. Rekapitulasi Perhitungan Debit Analisis Metode Mock (dalam $\mathrm{m}^{3} / \mathrm{det}$ )

Perhitungan debit andalan dilakukan dengan cara merangking (Metode Weilbull). Debit, yang telah diurutkan, dengan Metode Mock di Sungai Endikat Bengkok dalam rentang 2007-2016 (Tabel 5). Setelah debit sungai diurutkan dari terbesar ke terkecil, maka dilakukan perhitungan untuk mencari nilai debit andalan Q80 dengan cara interpolasi (Tabel 6).

Tabel 5. Debit yang sudah diurutkan dengan Metode Mock Sungai Endikat Bengkok 2007-2016

Tabel 6. Debit Andalan Q80 Metode Mock

\begin{tabular}{|c|c|}
\hline Bulan & Q80 (m3/det) \\
\hline Jan & 28.95 \\
\hline Feb & 26.14 \\
\hline Mar & 29.36 \\
\hline Apr & 48.15 \\
\hline Mei & 39.99 \\
\hline Jun & 17.75 \\
\hline Jul & 10.30 \\
\hline Agus & 6.18 \\
\hline Sept & 3.83 \\
\hline Okt & 2.23 \\
\hline Nov & 15.87 \\
\hline Des & 26.02 \\
\hline
\end{tabular}


Reni Andayani \& Ayu Marlina | Ketersediaan dan Pola Pemberian Air pada Daerah Irigasi Endikat Bengkok Kabupaten Muara Enim

Cantilever $\mid$ Volume : $9 \mid$ Nomor : $2 \mid$ Oktober 2020 | Hal. 83-88 $\mid$ ISSN: 1907-4247 (Print) $\mid$ ISSN: 2477-4863 (Online) $\mid$ Website: http://cantilever.id

Dari Tabel 6, didapatkan nilai debit terbesar pada bulan April sebesar $48,15 \mathrm{~m}^{3} / \mathrm{det}$ dan debit terkecil pada bulan Oktober sebesar $2,23 \mathrm{~m}^{3} / \mathrm{det}$

\subsection{Analisis Kebutuhan Air Irigasi}

\section{Perhitungan Curah Hujan Efektif (Re)}

Tahap pertama adalah menentukan curah hujan efektif. Data yang diperlukan dalam perhitungan ini menggunakan data curah hujan tengah bulanan dari tahun 2007 sampai 2016 pos hujan Pulau Panggung dan Muara Enim (Tabel 7)..

Tabel 7. Curah Hujan Setengah Bulanan 2007 - 2016

\begin{tabular}{|c|c|c|c|c|c|c|c|c|c|c|c|}
\hline \multirow{2}{*}{\multicolumn{2}{|c|}{ Bulan }} & \multicolumn{10}{|c|}{ Tahun } \\
\hline & & 200 & 2007 & 2009 & 2010 & 2011 & 2012 & 2013 & 2014 & 2015 & 2016 \\
\hline \multirow{2}{*}{$\mathbf{f}$} & & 26452 & 70.00 & 125.00 & 176.50 & 23.68 & 178.89 & 59.71 & 125.74 & 165.27 & 86.50 \\
\hline & 2 & 240.48 & 4200 & 125.00 & 17650 & 201.32 & 143.11 & 5429 & 11526 & $137.7 B$ & 86.50 \\
\hline \multirow{2}{*}{ Feb } & 1 & 135.00 & 25722 & 11100 & 131.76 & 73.48 & 108.60 & 7500 & 105.00 & $\pi .00$ & 1750 \\
\hline & 2 & 13500 & 205.78 & 11100 & 92.24 & 56.52 & 7240 & 750 & 73.50 & $\pi .00$ & 1775 \\
\hline \multirow{2}{*}{ Mar } & 1 & 19294 & 190.63 & 259.43 & 14350 & 224.00 & 207.00 & 88.80 & 173.83 & 177.27 & 283.13 \\
\hline & 2 & 135.06 & 114.38 & 194.57 & 14350 & 196.00 & 138.00 & 5920 & 124.17 & 147.73 & 169.88 \\
\hline \multirow{2}{*}{ Apr } & 1 & 20219 & 21188 & 27657 & 24250 & 21176 & 188.89 & 314.71 & 195.08 & 276.80 & 281.11 \\
\hline & 2 & 18381 & 12713 & 251.43 & 14550 & 148.24 & 151.11 & 20.29 & 121.92 & 24220 & 224.89 \\
\hline \multirow{2}{*}{ Mei } & 1 & 29867 & 13800 & 11550 & 94.50 & 264.00 & 144.44 & 209.40 & 90.42 & $161 \infty 0$ & 382.78 \\
\hline & 2 & 14933 & 9200 & 11550 & 94.50 & $176 . \infty$ & 1115.56 & 139.60 & 64.58 & 16100 & 3062 \\
\hline \multirow{2}{*}{ Jen } & 1 & 11029 & 21180 & 1050 & 63.50 & 118.80 & \begin{tabular}{|l|l}
90.50 \\
\end{tabular} & 88.00 & 120 & 87.82 & 62.50 \\
\hline & 2 & 82.71 & 14120 & 10.50 & 63.50 & 7920 & 90.50 & 66.00 & 0.80 & 7.18 & 62.50 \\
\hline \multirow{2}{*}{ bu } & 1 & 3200 & 81.00 & 11200 & 20000 & 123.13 & 65.23 & 50.73 & 25.64 & 35.00 & 264.0 \\
\hline & 2 & 32.00 & 54.00 & 11200 & 20000 & 7.88 & 40.7 & 4227 & 21.36 & 35.00 & $198 . \infty$ \\
\hline & 1 & 5950 & 150.00 & 186.00 & 86.29 & 151.25 & 11.50 & 71.00 & 13.00 & 32.50 & 82.50 \\
\hline & 2 & 5950 & 150.00 & 155.00 & 64.71 & 90.5 & 1150 & 71.00 & 13.00 & 3250 & 8250 \\
\hline \multirow{2}{*}{ Sep } & 1 & 48.50 & 51.76 & 20.43 & 14240 & 25.88 & 24.50 & 0.00 & 36.5 & 2750 & $175 \infty$ \\
\hline & 2 & 48.50 & 36.24 & 16957 & 124.60 & 18.12 & 24.50 & 0.00 & 26.25 & 2750 & $15 . \infty$ \\
\hline \multirow{2}{*}{0} & 1 & 88.00 & 74.67 & 19200 & 167.62 & $154 . \infty 0$ & 14.00 & 65.14 & 51.05 & 165.63 & 0.00 \\
\hline & 2 & 88.00 & 65.33 & 128.00 & 15238 & 110,00 & 10.00 & 48.86 & 45.95 & 99.38 & 0.00 \\
\hline \multirow{2}{*}{$\mathrm{N}$} & & 11526 & 20114 & 103,40 & 349.80 & 273.50 & 321.18 & 108.50 & 166.80 & 235.85 & 94.29 \\
\hline & 2 & 103774 & 18286 & 84.60 & 28620 & 15250 & 24.82 & 108.50 & 11120 & 202.15 & 85.71 \\
\hline & & 18833 & 145.64 & 259.10 & 27240 & 156.27 & 165.5 & 166.19 & 96.32 & 64.82 & 183.47 \\
\hline & 2 & 150.67 & 12136 & 24290 & 18160 & 136.73 & 14025 & 155.81 & 86.68 & 56.18 & 160.53 \\
\hline
\end{tabular}

Setelah didapat curah hujan setengah bulanan (untuk setiap tahunnya), data tersebut diurutkan dari yang terbesar sampai yang terkecil kemudian dicari curah hujan sebesar 80\% (R80), lihat Tabel 8 .

Setelah data curah hujan diurutkan dari terbesar sampe terkecil, maka dilakukan perhitungan R80 padi dengan cara interpolasi. Setelah nilai interpolasi R80 padi didapatkan maka dilakukan perhitungan curah hujan efektif (Tabel 9).

Berdasarkan hasil perhitungan curah hujan efektif maksimum untuk tanaman padi terjadi pada Bulan April periode I sebesar 9,36 $\mathrm{mm} / \mathrm{hr}$ sedangkan curah hujan minimum terjadi pada Bulan Agustus periode II sebesar $0,81 \mathrm{~mm} / \mathrm{hr}$.

\section{Analisis Kebutuhan Air Persiapan Lahan}

Kebutuhan air untuk penyiapan lahan menentukan kebutuhan air irigasi pada suatu irigasi. Pada DI Endikat Bengkok waktu untuk penyiapan lahan adalah 45 hari yaitu pada bulan FebruariMaret dan September-Oktober.
Tabel 8. Curah Hujan Setengah Bulanan R80

\begin{tabular}{|c|c|c|c|c|c|c|c|c|c|c|c|}
\hline \multirow{2}{*}{\multicolumn{2}{|c|}{$P=\frac{m}{n+1} r 100 \%$}} & 1 & 2 & 3 & 4 & 5 & 6 & 7 & 8 & 9 & 10 \\
\hline & & $9 \%$ & $18 \%$ & $27 \%$ & $36 \%$ & $45 \%$ & $55 \%$ & $64 \%$ & $73 \%$ & $82 \%$ & $91 \%$ \\
\hline \multirow{24}{*}{ 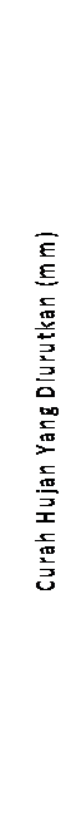 } & $\operatorname{Jan} 1$ & 26452 & 223.68 & 17889 & 176.50 & 16527 & 125.74 & 125.00 & 86.50 & 70.00 & 59.71 \\
\hline & $\mathrm{J}=2$ & 240.48 & 201.32 & 17650 & 143.11 & 137.73 & 125.00 & 11526 & 86.50 & 54.29 & 42.00 \\
\hline & F由1 1 & 25722 & 177.50 & 13500 & 131.76 & 11100 & 108.60 & 105.00 & 75.50 & 75.00 & 73.48 \\
\hline & F由 2 & 205.78 & 177.50 & 13500 & $111 \infty$ & 9224 & 5.50 & $\boldsymbol{5 . 0 0}$ & 73.50 & 72.40 & 56.52 \\
\hline & Mar 1 & 283.13 & 259.43 & 224.00 & 207.00 & 192.94 & 190.63 & 1727 & 173.83 & 143.50 & 88.80 \\
\hline & Mar 2 & 196.00 & 194.57 & 16.88 & 147.73 & 10.50 & 138.00 & 135.06 & 124.17 & 114.38 & 5920 \\
\hline & Apr 1 & 314.71 & 281.11 & 276.80 & 276.57 & 20.50 & 211.88 & 21.76 & 202.19 & 195.08 & 188.89 \\
\hline & $\operatorname{Apr} 2$ & 251.43 & 224.89 & 24220 & 220.29 & 183.81 & 151.11 & 148.24 & 145.50 & 127.13 & 127.92 \\
\hline & Mei1 & 38278 & 298.67 & 264.00 & 209.40 & 161.00 & 144 & 138.00 & 115.50 & 94.50 & 90.42 \\
\hline & $\mathrm{Mei} 2$ & 30622 & 176.00 & 16100 & 149.33 & 139.60 & 115.56 & 11550 & 94.50 & 92.00 & 6458 \\
\hline & $\operatorname{Jnn} 1$ & 21180 & 118.80 & 11029 & 10.50 & 9050 & 8000 & 87.82 & 63.50 & 62.50 & 1.20 \\
\hline & $\operatorname{Jan} 2$ & 14120 & 90.50 & 827 & 79.20 & 7318 & 66.00 & 63.50 & 62.50 & 10.50 & 0.80 \\
\hline & Jal1 & 264.00 & 220000 & 123.13 & $112 \infty 0$ & 8100 & 523 & 50.73 & 35.00 & 32.00 & 25.64 \\
\hline & $\mathrm{Jal} 2$ & 22000 & 198.00 & 11200 & 198.00 & 7388 & 50100 & 4227 & 40.77 & 35.00 & 32.00 \\
\hline & As 1 & 186.00 & 151.25 & 15000 & 86.29 & 8250 & 71.00 & 59.50 & 32.50 & 13.00 & 1150 \\
\hline & Af 2 & 155.00 & 150.00 & 90.5 & 8250 & 7100 & 6171 & 59.50 & 32.50 & 13.00 & 1150 \\
\hline & Sep 1 & 220.43 & $15 . \infty$ & 14240 & 5176 & 4850 & 35.75 & 27.50 & 25.88 & 24.50 & 0.00 \\
\hline & Sqp 2 & 175.00 & 169.57 & 124.60 & 48.50 & 3624 & 27.50 & 26.25 & 24.50 & 18.12 & 0.00 \\
\hline & Olat 1 & 19200 & 167.62 & 165.63 & $\mathbf{6} \mathbf{1 4}$ & 15400 & 800 & B..14 & 51.05 & 14.00 & 0.00 \\
\hline & 0lat 2 & 15238 & 128.00 & 11000 & 99.38 & 8810 & 653 & 48.86 & 45.95 & 10.00 & 0.00 \\
\hline & Nor 1 & 349.80 & 32.18 & 235.85 & 115.26 & $2 \mathbf{2 3 . 5 0}$ & 201.14 & 166.80 & 115.26 & 108.50 & 201.14 \\
\hline & Nov 2 & 28620 & 224.82 & 202.15 & 182.86 & 152.50 & 111.20 & 10850 & 103.74 & 85.71 & 84.60 \\
\hline & Des 1 & 27240 & 259.10 & 18833 & 183.47 & 166.19 & 165.75 & 156.27 & 145.64 & 96.32 & 64.82 \\
\hline & Des 2 & 24290 & 181.60 & 160.53 & 155.81 & 150.67 & 10025 & 136.73 & 121.36 & 86.68 & 56.18 \\
\hline
\end{tabular}

Tabel 9. Curah Hujan Setengah Bulanan R80

\begin{tabular}{|c|c|c|c|}
\hline \multicolumn{2}{|c|}{ Periode } & \multirow{2}{*}{\begin{tabular}{|c|}
$\mathrm{RS0}(\mathrm{m} \mathrm{m})$ \\
73.67 \\
\end{tabular}} & \multirow{2}{*}{$\begin{array}{r}\text { Re Padi } \\
3.44 \\
\end{array}$} \\
\hline 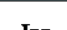 & 1 & & \\
\hline Jan & 2 & 61.44 & 2.69 \\
\hline \multirow{2}{*}{ Feb } & 1 & 75.11 & 3.51 \\
\hline & 2 & 72.64 & 3.91 \\
\hline \multirow{2}{*}{ Mar } & 1 & 150.24 & 7.01 \\
\hline & 2 & 116.55 & 5.44 \\
\hline \multirow{2}{*}{ Apr } & 1 & 200.61 & 9.36 \\
\hline & 2 & 131.21 & 6.12 \\
\hline \multirow{2}{*}{ Mei } & 1 & 99.17 & 4.63 \\
\hline & 2 & 92.56 & 4.32 \\
\hline \multirow{2}{*}{ Jnn } & 1 & 62.72 & 2.93 \\
\hline & 2 & 22.06 & 1.03 \\
\hline \multirow{2}{*}{ Jnl } & 1 & 32.67 & 1.52 \\
\hline & 2 & 36.28 & 1.69 \\
\hline \multirow{2}{*}{ Agust } & 1 & 17.33 & 0.81 \\
\hline & 2 & 17.33 & 0.81 \\
\hline \multirow{2}{*}{ Sep } & 1 & 24.81 & 1.16 \\
\hline & 2 & 19.54 & 0.91 \\
\hline \multirow{2}{*}{ Okt } & 1 & 22.23 & 1.04 \\
\hline & 2 & 17.99 & 0.84 \\
\hline \multirow{2}{*}{ Nop } & 1 & 110.00 & 5.13 \\
\hline & 2 & 89.72 & 4.19 \\
\hline \multirow{2}{*}{ Des } & 1 & 107.28 & 5.01 \\
\hline & 2 & 94.39 & 4.13 \\
\hline
\end{tabular}

Tabel 10. Rekapitulasi Perhitungan Kebutuhan Air untuk Persiapan Lahan

\begin{tabular}{|c|c|c|c|c|c|c|c|c|c|c|c|c|c|c|}
\hline \multirow{2}{*}{$\mathrm{N}_{0}$} & \multirow{2}{*}{ Parameter } & \multirow{2}{*}{ Satuan } & \multicolumn{12}{|c|}{ Bulan } \\
\hline & & & jan & $\mathrm{fb}$ & Mar & Apr & Mei & Jun & Jul & Agus & Sep & Olt & Nor & Des \\
\hline 1 & $\mathbf{D o}$ & mmhtai & 310 & 412 & 3.35 & 389 & 392 & 4.04 & 151 & 4.66 & 4.40 & 133 & $3 n$ & 328 \\
\hline 2 & B & molntii & 3.11 & 153 & 4.13 & 428 & 131 & 4.44 & 199 & 5.13 & 484 & 1.76 & 4.09 & 361 \\
\hline 3 & $\mathbf{P}$ & mmlari & 2 & 2 & 2 & 2 & 2 & 2 & 2 & 2 & 2 & 2 & 2 & 2 \\
\hline 1 & $\mathbf{M}$ & mm/ari & 5.11 & 653 & 6.13 & 628 & 631 & 6.41 & 699 & 7.13 & 684 & 6.76 & 6009 & 561 \\
\hline 5 & $\mathbf{I}$ & hri & 45 & 15 & 15 & 45 & 15 & 15 & 15 & 15 & 45 & 15 & 15 & 15 \\
\hline 6 & s & mm & 300 & 300 & 300 & 300 & 300 & 300 & 300 & 300 & 300 & 300 & 300 & 300 \\
\hline 1 & 1 & & 081 & 0.98 & 0.92 & 094 & 0.95 & 0.97 & 105 & 107 & 103 & 101 & 0.91 & 084 \\
\hline 8 & $\mathbf{I R}$ & mmhari & 9.7 & 10.4 & 103 & 103 & 10.4 & 10.4 & 105 & 109 & 1111 & 10.8 & 10.4 & 102 \\
\hline
\end{tabular}

Berdasarkan hasil perhitungan diatas, dapat dilihat bahwa kebutuhan air maksimum selama masa penyiapan lahan terjadi pada Bulan September 


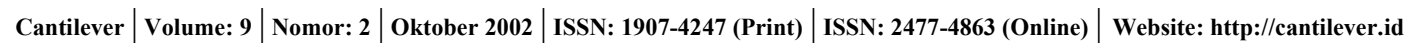
Reni Andayani \& Ayu Marlina | Ketersediaan dan Pola Pemberian Air pada Daerah Irigasi Endikat Bengkok Kabupaten Muara Enim

sebesar 11,1 $\mathrm{mm} / \mathrm{hr}$ sedangkan kebutuhan air minimum terjadi pada Bulan Januari sebesar 9,7 $\mathrm{mm} / \mathrm{hr}$.

\section{Analisis Perhitungan Kebutuhan Air Irigasi}

Tahap pertama adalah menentukan curah hujan efektif. Data yang diperlukan dalam perhitungan ini menggunakan data curah hujan tengah bulanan dari tahun 2007 sampai 2016 pos hujan Pulau Panggung dan Muara Enim (Tabel 11).

Tabel 11. Curah Hujan Setengah Bulanan R80

\begin{tabular}{|c|c|c|c|c|c|c|c|c|c|c|c|}
\hline \multirow{2}{*}{\multicolumn{2}{|c|}{$P=\frac{m}{n+1} 100 \%$}} & \multicolumn{2}{|c|}{12} & & \multicolumn{2}{|r|}{ 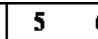 } & \multicolumn{2}{|l|}{7} & \multicolumn{2}{|c|}{, 10} \\
\hline & & \multirow{2}{*}{$\frac{\% \%}{26452}$} & \multirow{2}{*}{$\begin{array}{l}18 \% \\
23.68 \\
\end{array}$} & \multirow{2}{*}{$\begin{array}{l}27 \% \\
178.89 \\
\end{array}$} & \multirow{2}{*}{\begin{tabular}{|l|l}
$36 \%$ \\
176.50 \\
\end{tabular}} & \multirow{2}{*}{\begin{tabular}{|l|}
$45 \%$ \\
15527 \\
\end{tabular}} & \multirow{2}{*}{\begin{tabular}{|l|}
$55 \%$ \\
125.74 \\
\end{tabular}} & \multirow{2}{*}{\begin{tabular}{|l|}
$6 \%$ \\
$125 \%$ \\
\end{tabular}} & \multirow{2}{*}{\begin{tabular}{|l|}
$73 \%$ \\
86.50 \\
\end{tabular}} & \multirow{2}{*}{\begin{tabular}{|l|}
$82 \%$ \\
70.00 \\
\end{tabular}} & \multirow{2}{*}{$\begin{array}{l}91 \% \\
99.71 \\
\end{array}$} \\
\hline \multirow{24}{*}{ 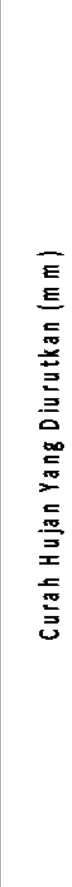 } & $\operatorname{Jn} 1$ & & & & & & & & & & \\
\hline & Ja 2 & 240.48 & 20132 & 17650 & 18.11 & \begin{tabular}{|l|l|}
137.73 \\
\end{tabular} & 125.00 & 11526 & \begin{tabular}{|l|l}
86.50 \\
\end{tabular} & 54.29 & 2010 \\
\hline & P由 1 1 & 572 & 1750 & 35.00 & 131.76 & 111.00 & 108.80 & 105.00 & 75.50 & 75.00 & 3.4 \\
\hline & P由 2 & 205.78 & 1750 & 35.00 & $111 \infty$ & 9224 & 73.50 & 75.00 & \begin{tabular}{|l}
73.50 \\
\end{tabular} & \begin{tabular}{|l|l|} 
& 72.40 \\
\end{tabular} & \\
\hline & Mar & & 259.43 & 24.00 & 277.00 & 19299 & 190.8 & 1727 & 173.83 & 43.5 & 3.8 \\
\hline & Mar 2 & 19600 & 19457 & 169.88 & 14.73 & 10.50 & 138.00 & 135.06 & \begin{tabular}{|l|l|}
124.17 \\
\end{tabular} & 114.38 & $m x$ \\
\hline & Apr 1 & 314.71 & 28111 & 276.80 & 226.57 & 20.50 & 211.88 & 21176 & \begin{tabular}{|l|}
202.19 \\
\end{tabular} & 155.08 & 188.8 \\
\hline & Apr 2 & 251.43 & 24.89 & 24220 & 220.29 & 183.81 & 151.11 & \begin{tabular}{|l|l|}
14824 \\
\end{tabular} & 145.50 & \begin{tabular}{|l|}
127.1 \\
\end{tabular} & $121 x$ \\
\hline & Mail & 38278 & 298.67 & 264.00 & 209.40 & 161.00 & $1 \mathrm{~mm}$ & 13800 & \begin{tabular}{|l|}
115.50 \\
\end{tabular} & \begin{tabular}{|l|l}
94.50 \\
\end{tabular} & 90.42 \\
\hline & Mi2 2 & 30627 & 17600 & 16100 & 149.33 & 139.60 & 1155 & 11550 & 94.50 & 92.00 & 64.58 \\
\hline & $\operatorname{Jn} 1$ & 21180 & 118.80 & 11029 & 1050 & 90.50 & 8800 & \begin{tabular}{|l|}
87.82 \\
\end{tabular} & \begin{tabular}{|l}
63.50 \\
\end{tabular} & 62.50 & 120 \\
\hline & $\mathrm{J}=2$ & 14120 & 90.50 & 8271 & 7920 & 7318 & 66.00 & 63.50 & 62.50 & 10.50 & 0.89 \\
\hline & Jل1 1 & 264.00 & 2000 & 13313 & 11200 & 8100 & 6523 & 50.73 & 35.00 & 32.00 & 25.64 \\
\hline & Jل1 2 & 20000 & 19800 & 11200 & 198.00 & 7388 & 5400 & 4227 & 40.77 & 35.00 & 200 \\
\hline & As 1 & 186.00 & 15125 & 150000 & 8629 & 8250 & 71.00 & \begin{tabular}{|l|}
59.50 \\
\end{tabular} & 32.50 & 13.00 & 11.50 \\
\hline & As 2 & 155.00 & 15000 & 90.75 & 8250 & 71.00 & 6971 & 59.50 & 32.50 & \begin{tabular}{|l}
13.00 \\
\end{tabular} & 11.50 \\
\hline & Sq 1 & 200.43 & 175.00 & 14240 & 5176 & 850 & 3673 & 27.50 & 25.88 & 24.50 & 0.00 \\
\hline & S甲 2 & 175.00 & 16957 & 124.60 & 4850 & 3624 & 27.50 & 26.25 & 24.50 & 18.12 & 100 \\
\hline & Ox & 19200 & 17.62 & 165.63 & 65.14 & 15400 & 8800 & 65.14 & 51.05 & \begin{tabular}{|l|l} 
& 14.00 \\
\end{tabular} & 100 \\
\hline & Old2 2 & 15238 & 12800 & 110.00 & 9938 & 88100 & 6533 & 48.86 & \begin{tabular}{|l|l|}
45.95 \\
\end{tabular} & 10.00 & 100 \\
\hline & Nor 1 & 349.80 & 321.18 & 235.85 & 115.26 & 213.50 & 201.11 & 166.80 & $\mid$\begin{tabular}{|l}
115.26 \\
\end{tabular} & 108.5 & 201.14 \\
\hline & Nor 2 & 28620 & 224.82 & 202.15 & 128.86 & 152.50 & 111.20 & 18850 & $\mid 103.74$ & 85.71 & 84.60 \\
\hline & & & & 8833 & 18.47 & 166.19 & 165.5 & 15627 & $\mid 145.64$ & 96.32 & 4.8 \\
\hline & & $242 \times 0$ & 18160 & 160.53 & | 15.81 & | $1>0,0$ & 100.5 & 136.73 & 181.36 & 86.68 & 56.1 \\
\hline
\end{tabular}

Setelah data curah hujan diurutkan dari terbesar sampe terkecil maka dapat dilakukan perhitungan $\mathrm{R}_{80}$ padi dengan cara interpolasi. Setelah nilai interpolasi $\mathrm{R}_{80}$ padi didapatkan maka dilakukan perhitungan untuk curah hujan efektif (Tabel 12).

Tabel 3.13 menunjukan pola tanam di DI Endikat Bengkok. Persiapan lahan di bulan selama 45 hari , dan masa transplantasi selama 4 bulan atau 120 hari. Persiapan lahan untuk penanaman padi pertama dimulai bulan Februari dan bulan September untuk penanaman kedua. Kemudian pada bulan Agustus tanah di biarkan bera (sistem pengambilan kesuburan tanah dengan cara membiarkan tanah tanpa ditanami). Petani di D.I. Endikat Bengkok tidak melakukan penanaman palawija. Setelah pola tanam masyarakat di D.I. Endikat Bengkok diketahui, dapat dihitung kebutuhan air irigasi di sawah (Tabel 14).
Tabel 12. Curah Hujan Setengah Bulanan R80 dan Curah Hujan Efektif Padi

\begin{tabular}{|c|c|c|r|}
\hline \multicolumn{2}{|c|}{ Periode } & \multirow{2}{*}{ R80 (mm) } & Re Padi \\
\cline { 2 - 4 } Jan & 1 & 73.67 & \\
\cline { 2 - 4 } & 2 & 61.44 & 3.44 \\
\hline \multirow{2}{*}{ Feb } & 1 & 75.11 & 2.69 \\
\cline { 2 - 4 } & 2 & 72.64 & 3.51 \\
\hline \multirow{2}{*}{ Mar } & 1 & 150.24 & 3.91 \\
\cline { 2 - 4 } & 2 & 116.55 & 7.01 \\
\hline \multirow{2}{*}{ Apr } & 1 & 200.61 & 5.44 \\
\cline { 2 - 4 } & 2 & 131.21 & 9.36 \\
\hline \multirow{2}{*}{ Mei } & 1 & 99.17 & 6.12 \\
\cline { 2 - 4 } & 2 & 92.56 & 4.63 \\
\hline \multirow{2}{*}{ Jun } & 1 & 62.72 & 4.32 \\
\cline { 2 - 4 } & 2 & 22.06 & 2.93 \\
\hline \multirow{2}{*}{ Jul } & 1 & 32.67 & 1.03 \\
\cline { 2 - 4 } & 2 & 36.28 & 1.52 \\
\hline \multirow{2}{*}{ Agust } & 1 & 17.33 & 1.69 \\
\cline { 2 - 4 } & 2 & 17.33 & 0.81 \\
\hline \multirow{2}{*}{ Sep } & 1 & 24.81 & 0.81 \\
\cline { 2 - 4 } & 2 & 19.54 & 1.16 \\
\hline \multirow{2}{*}{ Okt } & 1 & 22.23 & 0.91 \\
\cline { 2 - 4 } & 2 & 17.99 & 1.04 \\
\hline \multirow{2}{*}{ Nop } & 1 & 110.00 & 0.84 \\
\cline { 2 - 4 } & 2 & 89.72 & 5.13 \\
\hline \multirow{2}{*}{ Des } & 1 & 107.28 & 4.19 \\
\cline { 2 - 4 } & 2 & 94.39 & 5.01 \\
\hline \multirow{2}{*}{} & & & 4.13 \\
\hline
\end{tabular}

Tabel 13. Pola Tanam Padi-D.I. Endikat Bengkok

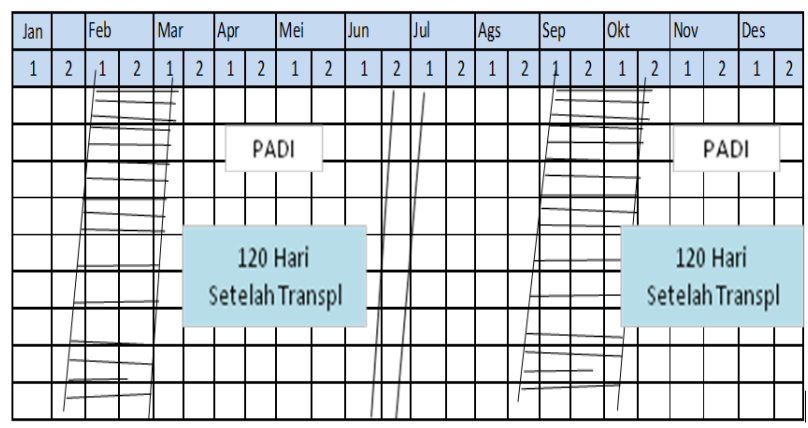

Tabel 14. Kebutuhan Air Irigasi D.I. Endikat Bengkok

\begin{tabular}{|c|c|c|c|c|c|c|c|c|c|}
\hline \multirow{2}{*}{\multicolumn{2}{|c|}{ Periode }} & Eto & $\mathbf{P}$ & $\operatorname{Re}$ & WLR & \multirow[t]{2}{*}{ C } & \multirow[t]{2}{*}{$\begin{array}{c}\text { ETc } \\
\mathrm{mm} / \mathrm{h}\end{array}$} & \multirow[t]{2}{*}{$\begin{array}{l}\text { NFR } \\
\mathrm{mm} / \mathrm{h}\end{array}$} & \multirow[t]{2}{*}{$\begin{array}{c}\text { DR } \\
\mathrm{L} / \mathrm{dt} / \mathrm{ha} \\
\end{array}$} \\
\hline & & $\mathrm{mm} / \mathrm{h}$ & $\mathrm{mm} / \mathrm{h}$ & $\mathrm{mm} / \mathrm{h}$ & $\mathrm{mm} / \mathrm{h}$ & & & & \\
\hline \multirow{2}{*}{ Nov } & 1 & 3,10 & 2,0 & 3,44 & 1,1 & 1,1 & 3,8 & 3,4 & 0,61 \\
\hline & 2 & 3,10 & 2,0 & 2,69 & 2,2 & 1,1 & 7,5 & 9,0 & 1,60 \\
\hline \multirow{2}{*}{ Des } & 1 & 4,12 & 2,0 & 3,51 & 1,1 & 1,1 & 5,0 & 4,6 & 0,81 \\
\hline & 2 & 4,12 & 2,0 & 3,91 & 1,1 & 1,1 & 5,0 & 4,2 & 0,74 \\
\hline \multirow{2}{*}{ Jan } & 1 & 3,75 & 2,0 & 7,01 & & 1,05 & 0,0 & 0,0 & 0,00 \\
\hline & 2 & 3,75 & 2,0 & 5,44 & & 0,95 & 0,0 & 0,0 & 0,00 \\
\hline \multirow{2}{*}{ Feb } & 1 & 3,89 & 2,0 & 9,36 & & 0 & 0,0 & 0,0 & 0,00 \\
\hline & 2 & 3,89 & 2,0 & 6,12 & & 1,1 & 10,3 & 6,2 & 1,10 \\
\hline \multirow{2}{*}{ Mar } & 1 & 3,92 & 2,0 & 4,63 & & 1,1 & 10,3 & 7,7 & 1,36 \\
\hline & 2 & 3,92 & 2,0 & 4,32 & & 1,1 & 10,3 & 8,0 & 1,42 \\
\hline \multirow{2}{*}{ Apr } & 1 & 4,04 & 2,0 & 2,93 & 1,1 & 1,1 & 4,9 & 5,1 & 0,90 \\
\hline & 2 & 4,04 & 2,0 & 1,03 & 1,1 & 1,1 & 4,9 & 7,0 & 1,24 \\
\hline \multirow{2}{*}{ Mei } & 1 & 4,54 & 2,0 & 1,52 & 2,2 & 1,1 & 11,0 & 13,7 & 2,43 \\
\hline & 2 & 4,54 & 2,0 & 1,69 & 1,1 & 1,1 & 5,5 & 6,9 & 1,23 \\
\hline \multirow{2}{*}{ Jun } & 1 & 4,66 & 2,0 & 0,81 & 1,1 & 1,1 & 5,6 & 7,9 & 1,41 \\
\hline & 2 & 4,66 & 2,0 & 0,81 & & 1,05 & 0,0 & 1,2 & 0,21 \\
\hline \multirow{2}{*}{ Jul } & 1 & 4,40 & 2,0 & 1,16 & & 0,95 & 0,0 & 0,8 & 0,15 \\
\hline & 2 & 4,40 & 2,0 & 0,91 & & 0 & 0,0 & 1,1 & 0,19 \\
\hline \multirow{2}{*}{ Ags } & 1 & 4,33 & 2,0 & 1,04 & & & 0,0 & 0,0 & 0,00 \\
\hline & 2 & 4,33 & 2,0 & 0,84 & & & 0,0 & 0,0 & 0,00 \\
\hline \multirow{2}{*}{ Sep } & 1 & 3,72 & 2,0 & 5,13 & & 1,1 & 10,1 & 7,0 & 1,24 \\
\hline & 2 & 3,72 & 2,0 & 4,19 & & 1,1 & 10,1 & 7,9 & 1,41 \\
\hline \multirow{2}{*}{ Okt } & 1 & 3,28 & 2,0 & 5,01 & & 1,1 & 9,9 & 6,9 & 1,23 \\
\hline & 2 & 3,28 & 2,0 & 4,13 & 1,1 & 1,1 & 4,0 & 2,9 & 0,52 \\
\hline
\end{tabular}


Berdasarkan hasil perhitungan, dapat dilihat bahwa kebutuhan air irigasi maksimum terjadi pada bulan Mei periode I sebesar $2,43 \mathrm{l} / / \mathrm{dt} / \mathrm{ha}$ dan kebutuhan air minimun terjadi pada musim panen dan pada saat bera yaitu pada bulan Januari, Juli dan Agustus (Tabel 15). Terlihat bahwa kebutuhan air terbesar terjadi pada bulan Mei, dikarenakan bulan tersebut terjadi penggantian lapisan air, namun curah efektif kecil.

Tabel 15. Rekapitulasi Kebutuhan Air irigasi

\begin{tabular}{|l|r|}
\hline \multicolumn{1}{|c|}{ Bulan } & \multicolumn{1}{c|}{$\begin{array}{r}\text { Kebutuhan Air } \\
\mathrm{m}^{3} / \mathrm{det}\end{array}$} \\
\hline November & 25,22 \\
\hline Desember & 17,76 \\
\hline Januari & 0,00 \\
\hline Februari & 12,48 \\
\hline Maret & 31,69 \\
\hline April & 24,39 \\
\hline Mei & 41,76 \\
\hline Juni & 18,51 \\
\hline Juli & 3,92 \\
\hline Agustus & 0,00 \\
\hline September & 30,21 \\
\hline Oktober & 19,95 \\
\hline
\end{tabular}

\subsection{Analisis Ketersedian dan Pola Pemberian Air}

Pada Tabel 3.16. dapat dilihat perbandingan antara ketersediaan air Q80\% sungai Endikat Bengkok dengan kebutuhan air Daerah Irigasi Endikat Bengkok. Ketersediaan air di Sungai Endikat Bengkok tidak dapat memenuhi kebutuhan air pada bulan November, Maret, Mei, Juni, September dan Oktober.

Tabel 3.16. Rekapitulasi Ketersediaan Air Q80 dan Kebutuhan Air Irigasi

\begin{tabular}{|l|r|r|}
\hline \multicolumn{1}{|c|}{ Bulan } & \multicolumn{1}{r|}{$\begin{array}{r}\text { Kebutuhan Air } \\
\mathrm{m}^{3} / \mathrm{det}\end{array}$} & $\begin{array}{c}\text { Debit Andalan } \\
\mathrm{Q}_{80 \%}\end{array}$ \\
\hline November & 25,22 & 15,87 \\
\hline Desember & 17,76 & 26,02 \\
\hline Januari & 0,00 & 28,95 \\
\hline Februari & 12,48 & 26,14 \\
\hline Maret & 31,69 & 29,36 \\
\hline April & 24,39 & 48,15 \\
\hline Mei & 41,76 & 39,99 \\
\hline Juni & 18,51 & 17,75 \\
\hline Juli & 3,92 & 10,3 \\
\hline Agustus & 0,00 & 6,18 \\
\hline September & 30,21 & 3,83 \\
\hline Oktober & 19,95 & 2,23 \\
\hline
\end{tabular}

Jika persediaan air cukup maka faktor $\mathrm{K}=1$, sedangkan jika persediaan air kurang maka nilai $\mathrm{K}<1$. Nilai $\mathrm{K}$ adalah perbandingan antara ketersediaan dibagi dengan kebutuhan air, sehingga didapatkan nilai K dibulan November, Maret, Mei, Juni, September dan Oktober berturut sebesar $\mathrm{K}=0,63 ， 0,92 ， 0,96 ， 0,96,0,13$ dan 0,11. Pola pemberian air pada Daerah Irigasi Endikat Bengkok tidak dapat dilakukan dengan cara menerus, dikarenakan ketersediaan tidak mencukupi atau $\mathrm{K}<1$. Sehingga, pola pemberian air yang dapat dilakukan adalah dengan cara bergilir.

\section{KESIMPULAN}

\subsection{Kesimpulan}

Berdasarkan hasil analisis pada penelitian yang telah dilakukan dapat disimpulkan bahwa debit andalan untuk irigasi atau ketersediaan air Q80\% maksimum Sungai Endikat Bengkok terjadi pada bulan April $\left(=48,15 \mathrm{~m}^{3} / \mathrm{det}\right)$, dan debit terkecil pada bulan Oktober $\left(=2,23 \mathrm{~m}^{3} / \mathrm{det}\right)$. Pola pemberian air pada Daerah Irigasi Endikat Bengkok tidak dapat dilakukan dengan cara menerus, dikarenakan ketersediaan tidak mencukupi atau $\mathrm{K}<1$, sehingga pola pemberian air yang lebih tepat dengan cara bergilir berdasarkan kriteria perencanaan irigasi. Diperlukan penelitian lanjutan terkait proyeksi apabila pencetakan sawah dilakukan secara keseluruhan.

\section{UCAPAN TERIMA KASIH}

Ucapan terima kasih kepada Yayasan Pendidikan Nasional Tridinanti (YPNT) atas dukungan pendanaan pada penelitian ini.

\section{REFERENSI}

Sari, I. K., Limantara, L. M., \& Priyantoro, D. (2011). Analisa Ketersediaan dan Kebutuhan Air pada DAS Sampean. Jurnal Teknik Pengairan, 2(1).

Kundimang, V. I., Hendratta, L, A., Wuisan, E, M. (2015), Analisa Ketersediaan Air Sungai Talawan Untuk Kebutuhan Irigasi di Daerah Irigasi Talawan Meras dan Talawan Atas, Jurnal Tekno, Vol. 64.

Priyonugroho, A. (2014). Analisis Kebutuhan Air Irigasi (Studi Kasus Pada Daerah Irigasi Sungai Air Keban Daerah Kabupaten Empat Lawang). Jurnal Teknik Sipil dan Lingkungan, 2(3), 457-470.

Wijaksono, M. A., Daud, A., \& Indriyati, C. (2018). Analisis Ketersediaan dan Kebutuhan Air Pada Bendung Perjaya Sungai Komering. Tugas Akhir. Inderalaya: Universitas Sriwijaya. 